\title{
EGY ISMERETLEN ÍRÁS ÉS NYELV MEGFEJTÉSE: A KITAN
}

\section{THE DECIPHERMENT OF AN UNKNOWN SCRIPT AND LANGUAGE: THE KHITAN}

\author{
Róna-Tas András \\ az MTA rendes tagja, professor emeritus \\ Szegedi Tudományegyetem Bölcsészet- és Társadalomtudományi Kar Altajisztikai Tanszék, Szeged \\ aronatas3@t-online.hu
}

\begin{abstract}
ÖSSZEFOGLALÁS
A cikk a 10-13. században Észak-Kínában használt és a 20. században felfedezett két kitan írás megfejtéséről számol be. Tárgyalja a Liao dinasztiát megalapító kitanok népnevével és történetével kapcsolatos új ismereteket, áttekinti a kutatástörténetet. A két kitan írás bemutatása után összefoglalja az írások megfejtésének jelenlegi helyzetét, bemutatja a szövegeket tartalmazó kis kitan írással írt korpuszt, majd elemzi a kitan nyelv főbb sajátosságait és helyét az altaji nyelvek között. Megállapítja, hogy a kitan a mongol nyelvekkel közös alapnyelvre vezethető vissza. A cikk a kitan nyelv magyar vonatkozásainak ismertetésével zárul.
\end{abstract}

\section{ABSTRACT}

The paper discusses the discovery of the two Khitan scripts, which were used in North China in the $10^{\text {th }}-13^{\text {th }}$ centuries. It gives an overview on the recent researches on the ethnonym Khitan, on the history of the Liao Empire founded by them, and discusses the earlier attempts of the decipherment of the two scripts. After introducing the newly published corpus of the Khitan Small Script, the paper summarizes the present state of the decipherment of the scripts. This is followed by a short outline of the Khitan language and its place among the Altaic languages. The author states that Khitan and the Mongolic languages go back to a common proto-language. Finally the paper deals with some Khitan words the parallels of which, as Turkic loans, are present also in Hungarian.

Kulcsszavak: kitan népnév, kitan nyelv, kitan írások, kis kitan írás, kitan feliratok, kitan szövegkorpusz, Liao dinasztia, kitan-magyar párhuzamok, pinjin: Qidan

Keywords: Khitan ethnonym, Khitan language, Khitan scripts, Khitan Small Script, Khitan inscriptions, Khitan texts, Liao dynasty, Khitan-Hungarian linguistic parallels, pinyin: Qidan 


\section{BEVEZETŐ}

A huszadik század közepén három jelentős nép által hátrahagyott íráscsoport volt megfejtetlen: a tangut, a dzsürcsi és a kitan. A tangut írást a tangut, kínai nevén Xi Xia (nyugati Hszi) birodalomban használták, amely Belső-Ázsiában 1038 és 1227 között állt fent, Dzsingisz kán mongoljai döntötték meg. A dzsürcsi írást a mandzsuk ősi rokonai használták, kínai nevükön a nüzhenek, birodalmuk 1127 és 1234 között virágzott, és szintén a mongolok semmisítették meg. A huszadik század végére ezt a két írást megfejtették, az írásokkal írt nyelvemlékeket elkezdték publikálni, feldolgozásuk jelenleg is folyamatban van. A tangut nyelv a tibeti távoli rokonának, a dzsürcsi a mandzsu nyelv közeli rokonának bizonyult.

A harmadik nép, amelynek írása, pontosabban írásai a huszadik század közepén még megfejtetlenek voltak, a kitan, ennek megfejtéséről fog az alábbi tanulmány szólni.

\section{A NÉV}

A kitan népnév először a nyolcadik századi orhoni, keleti ótörök nyelvü feliratokban tünik fel kitany alakban. A név végén álló /ny/ hangnak a türk rovásábécében külön jele volt. A keleti ótörök nyelvnek két fő nyelvjárása közül az egyikben az /ny/ hangot /n/, a másikban/j/ váltotta fel. Így alakult ki a nép kitan és kitaj neve. A kitaj népnév nemsokára egész Kína nevévé is vált, ezt vették át az oroszok, akiknek a nyelvében ma a kitaj kínait jelent. Kataj alakban többek között Marco Polo révén terjedt el, szintén mint Kína neve. A kitan alakot vették át a kínaiak, és ma a nemzetközi tudomány a kitan alakot használja, hogy megkülönböztesse az oroszok által Kínára használt kitaj formától. Korábban a magyar szaktudományban ezt a népet kitajnak nevezték. Mai, a kínaiak által használt pinjin átirással: qidan

\section{A KITAN TÖRZSSZÖVETSÉG}

A különböző kitan törzsek változó vezetésü szövetségeit a 6. századtól tudjuk nyomon követni. A 9. század utolsó éveiben, a 10. század elején, tehát a magyar honfoglalással nagyjából egy időben, elfoglalták Észak-Kínát. 925-ben vezetőjük megalapította a Liao dinasztiát, amelyet 1127-ben a fentebb már említett dzsürcsik döntenek meg. Ekkor a kitanok egy része nyugatnak indult, ezeket karakitajnak, fekete kitajnak nevezték. Ez utóbbi, hamar eltörökösödött csoport híre eljutott a Magyar Királyságba is, ahol a Képes Krónikánkban gens kytanorum alakban szerepelnek. A Liao állam vezető törzsszövetségét különböző nyelveket beszélö csoportok alkották, a kitanok mellett érdemes kiemelni a török nyelvü ujgurokat, akik a vezető kitan nemzetséggel házassági szövetségben éltek. Ez azt jelentette, hogy az uralkodó kitan nemzetség fiainak ujgur anyjuk volt, és az ujgur anyai nagybácsik fontos szerepet játszottak a Liao dinasztia életében. 


\section{RÖVID KUTATÁSTÖRTÉNET}

A kínai forrásokkal foglalkozó kutatók már korán rábukkantak a Liao dinasztia és uralkodó népei történetére. Többen is foglalkoztak a Liao dinasztia „hivatalos” történetében a Liaosiben előforduló adatokkal. Egy amerikai és egy kínai tudós nagy monográfiát írt a Liao dinasztia társadalmi, politikai és gazdasági szervezetéről (Wittfolgel-Fêng, 1949). A kínai források megemlékeztek a kitanok írásáról is, említést tettek arról, hogy kétféle írásuk is volt. Hosszú ideig azonban sem a kínai, sem a nyugati tudomány nem rendelkezett kitan írásos emlékekkel.

A fordulat 1923-ban következett be, amikor egy Pekingben élö francia tudós-misszionárius, Louis Kervyn megvizsgált néhány 1922-ben, egy Liao császár sírjából előkerült feliratot. Ezekről sikerült megállapítania, hogy kitan írással íródtak. Eredményeit egy pekingi misszionáriusok által kiadott folyóiratban közölte (Kervyn, 1923a). Erre figyelt fel a nagy francia orientalista, Paul Pelliot, és adta ki még ugyanabban az évben Kervyn cikkét megjegyzéseivel együtt Párizsban (Kervyn, 1923b). A Párizsban Pelliot-nál tanuló Ligeti Lajos azonnal felismerte a felfedezés jelentőségét, bekapcsolódott a kutatásba, és 1927-ben egy magyar nyelvü cikkben összefoglalta a kutatások helyzetét és tennivalóit (Ligeti, 1927). Bár a feliratok kitan voltát sikerült azonosítani, megfejteni és elolvasni senki nem tudta őket. Noha a Liao dinasztia alatt írt emlékek száma lassan gyarapodott, egészen a 1960-as évekig kellett várni, hogy a két kitan írás emlékeit a tudósok el tudják választani egymástól. Ekkor derült ki, hogy az egyik kitan írás lényegében szóírás, míg a másik szótagírás. Az előzőt nagy vagy lineáris írásnak (Khitan Large or Linear Script), a másikat kis vagy csoportírásnak (Khitan Small or Assembled Script) is nevezik.

A két írás emlékeinek gyüjtése folytatódott, néhány emlék fényképét a kínai kutatók meg is jelentették, az írások megfejtése azonban nehezen indult meg. Orosz, japán és kínai kutatók versenyeztek elsősorban a nagy kitan írás emlékeinek vizsgálatában, az 1980-as évek végéig azonban alig jutottak komoly eredményre. A fordulat akkor következett be, amikor két vezető kínai kutató, Liu Fengzhu és Csinggeltei a kis kitan írás felé fordult. Az 1990-es évek elején a kínai Höhhot (Köke Qota) egyetemén oktató Csinggelteinek sikerült egy ütőképes kutatócsoportot kialakítania. A kutatások első eredményeiről angol nyelven elöször Budapesten, az Acta Orientalia Hungarica 2002-es számában számoltak be (Chinggeltei, 2002). Kara György a világ írásairól szóló nagy monográfiában (Daniels-Bright, 1996) foglalta össze a legfontosabb, addig rendelkezésre álló ismereteket (Kara, 1996).

A felgyorsult kutatások újabb eredményeit Daniel Kane összegezte angol nyelven (Kane, 2009). Két kis kitan írással írt felirat filológiailag is példamutatóan feldolgozott angol nyelvű kiadása Wu Yingzhe és Juha Janhunen 2010-ben megjelent közös munkája. 2015 végén két magyar szakember, Apatóczky Ákos Bertalan és Kempf Béla utaztak Köke Qotába, hogy egyrészt a kitan írások megfejtése 
céljából történő együttmüködésről tárgyaljanak, másrészt a kitan vonatkozású és Európában nehezen hozzáférhető publikációkat összegyüjtsék a Szegedi Tudományegyetem Könyvtára számára. Mindkét törekvésük sikerrel járt (Apatóczky-Kempf, 2017). Bár Csinggeltei 2013-ban elhunyt, a tanítványai folytatták a munkát, és a teljes addig ismert kis kitan írással írt korpuszt számítógépre vitték. Ennek anyaga 2017-ben három vaskos kötetben jelent meg (CWJ = ChinggelteiWu-Jiruhe, 2017, lásd Apatóczky-Róna-Tas, 2019). Ugyancsak 2017-ben jelent meg az Acta Orientalia Hungarica kitan kutatásoknak szentelt füzete, amelyben japán, magyar, kínai, francia és amerikai kutatók a nemzetközi együttmüködés eredményeiről számoltak be. Az ott publikált cikkek közül is ki kell emelni Wu Yingzhe, Jiruhe és Peng Daruhan (2017) cikkét, amely a lineáris kitan és a kis kitan írás közötti kapcsolatokat tárgyalja.

\section{AZ ÍRÁSOK}

A nagy kitan írást 920-ban állították össze. Kínai mintára készült, de írásjelei csak részben hasonlítanak kínai írásjelekre, s ritkán van valami közük egymáshoz. Az írás szóírás, de ahogy a japánnak is, ennek az írásnak is meg kellett küzdenie a nyelv képzős és ragozó rendszerével. A rendszer logografikus, vagyis a jelentéshez kötött, a kiejtést „tudni kell”. A nagy kitan írás néhány írásjelét már megfejtették, ugyanis a kínai párhuzamos szövegek alapján azonosították a szó jelentését, majd vagy kínai átírásos anyagból vagy a kis kitan írás segítségével megállapították a kiejtését. A nagy kitan írás és tizennyolc eddig felfedezett emléke tehát egyelöre nyelvi rekonstrukció céljaira nem használható fel, de történeti forrásként természetesen van jelentősége. Más a helyzet a kis kitan írással.

A kis kitan írásról, a Liaosi egy helyének félreértése alapján, hosszú ideig azt hitték, hogy az az ujgur írással azonos, vagy közel áll ahhoz. Ezt gondolta Ligeti is. Ma már tudjuk, hogy a kis kitan írást bizonyos megszorításokkal szótagírásnak lehet jellemezni. Jeleinek nincs közük egyetlen eddig ismert íráséhoz sem, bár léteznek különféle javaslatok. Jelenleg 450 jelet tudunk megkülönböztetni. A 450 jelből 293-nak van „megfejtése”. A 293-ból 26-nak csak a jelentését ismerjük, 267-nek van ún. olvasata. Ezek az olvasatok, szaknyelven romanizációk, abból adódnak, hogy a megfejtés során a kitan szavakat kínai szavakkal azonosították. Ezek a kis kitan írással írt szavak olvasatai a kínai személy- és földrajzi nevek, címek korabeli, tehát 10-13. századi kínai kiejtésén alapszanak. Mivel az egykorú kínai és kitan hangrendszer sok vonatkozásban eltért, a kitan jelek csak bizonyos határok között értelmezhetők hangtanilag. Ehhez járul még két nehézség. Az egyik, hogy a jelek többfunkciósak. Például a $<\mathrm{t}>$ jele olvasható /et/-nek, /t/-nek, /te/-nek. A másik, hogy a kínai kollégák a latin írásjelek kiválasztásánál a mai kínai latin betüs hivatalos átírás, a pinjin jelöléseit használták. 
Az írásjelek által jelölt egységek lehetnek egy, két és három hangot jelölők, jelölhetnek mássalhangzókat (C) és magánhangzókat (V): tehát C-, V-, CV-, VC-, CVC-, VCV-csoportokat, ezért csak erős megkötéssel lehet az írást szótagírásnak, szillabikusnak nevezni.

A 450 írásjelet három csoportra oszthatjuk. Az alapjelek mellett vannak variánsok, azaz alloglifek és vannak ún. heteroglifek, vagyis olyan jelek, amelyek ugyan rajzukban teljesen eltérnek az alapjelektől, de olvasatuk azonos. Például az /en/ szótagnak három olyan írásjele van, amely alakilag alig tér el (alloglif), míg egy negyedik lényegesen különbözik (heteroglif, lásd a mellékelt táblát). A most folyó kutatásokban egyelöre 47 alloglifet és 188 heteroglifet azonosítottunk.

Igaz ugyan, hogy a 450 írásjelből csak 267-nek van olvasata, ami csak közel $60 \%$-a az összes jelnek, azonban ezek az írásjelek a leggyakoribbak. A még meg nem fejtett írásjelek, néhány kivételtől eltekintve, ritkán, egyszer-kétszer fordulnak elő. Minden írásjelnek van egy háromjegyủ azonosító száma. Ez azért fontos, mert a kutatómunka során kiderülhet, és már néhányszor ki is derült, hogy az írásjel addig elfogadott olvasatát meg kell változtatni, ilyenkor az azonosító szám segíti a kutatókat. Az írásjeleknek elkészült a számítógépen használható fontja (Menksoft1), s az a publikációkban könnyen használható.

Az írásjelek csoportokban jelennek meg. Ezek a csoportok lehetnek alapszavak, képzett vagy ragozott alakok. Egy csoport maximum nyolc jelből állhat:
a b
c d
e $f$
$\mathrm{g} \mathrm{h}$

A csoportok függőlegesen követik egymást, a függőleges sorok jobbról balra haladnak.

\section{A KORPUSZ}

A kis kitan írással írt szövegek három csoportra oszthatók. Az elsőbe a nagy, többségükben sír- vagy dicsőítő feliratok tartoznak. A legrégibb 1053-ból, az utolsó 1175-ből, tehát a következő dinasztia első éveiből származik. A második csoportba kisebb, föleg tárgyakon vagy pénzeken, barlangfalon előforduló néhány szavas szövegek sorolhatóak. A harmadik csoport egyelöre egy kéziratból áll, néhány további töredék azonosítása még nem lezárt. A Kínában hozzáférhető kis kitan írással írt anyagot 2016-2017-ben számítógépre vitték, és 2017-ben a fent említett háromkötetes müben (CWJ) publikálták. Ez nem tartalmazza az Oroszországban őrzött kéziratot és a munka lezárását követően felfedezett nyolc feliratot. Az anyag így is monumentális, 44 nagy felirat és 17 
kis felirat anyaga jól kezelhetően és egységes elvek alapján megjelenítve kerül a kutató kezébe. Az index több mint 10000 egység mintegy 100000 előfordulását tartalmazza.

\begin{tabular}{|c|c|c|c|c|}
\hline \multicolumn{2}{|c|}{$\begin{array}{l}\text { Az 1114-es Xiao Dilu felirat } \\
\text { kezdó szavai }^{1}\end{array}$} & \multicolumn{3}{|c|}{$\begin{array}{c}\text { Az e-vel kezdődő kitan jelek és } \\
\text { átírásuk }\end{array}$} \\
\hline 外兊 & bu.d & átírás & kitan jel & $\begin{array}{l}\text { azonosító } \\
\text { sorszám }\end{array}$ \\
\hline 力赤 & na.ha & $<\mathrm{e}>$ & 菼 & $(348)$ \\
\hline \multirow{3}{*}{ 出 资 } & \multirow{2}{*}{ an.er 2} & $<\mathrm{e}_{2}>$ & 夯 & (109) \\
\hline & & $<\mathrm{e}_{3}>$ & 勞 & $(264.1)$ \\
\hline & en & $<\mathrm{em}>$ & 百 & $(021)$ \\
\hline \multirow{2}{*}{ 本 4} & \multirow[b]{2}{*}{ irā.1 } & <ém> & 조 & $(270)$ \\
\hline & & $<\mathrm{em}_{2}>$ & 金 & $(257)$ \\
\hline \multirow{3}{*}{ 事及 } & \multirow{2}{*}{ O.ó } & $<\mathrm{emu}>$ & モ & $(026)$ \\
\hline & & $<\mathrm{emu}^{\mathrm{o}}>$ & モ & $(027)$ \\
\hline & ón & $<\mathrm{en}>$ & 來 & $(140)$ \\
\hline \multirow{2}{*}{ 令用 } & \multirow{2}{*}{ t'.il } & <én> & 与 & $(361)$ \\
\hline & & <én ${ }_{2}>$ & 与 & $(100)$ \\
\hline & uh & $<$ én $3>$ & 与 & $(100.10)$ \\
\hline \multirow[t]{2}{*}{ 分忝 } & pu.ši & <én $4>$ & 占 & $(100.20)$ \\
\hline & \multirow[b]{2}{*}{ en } & $<\bar{e} n>$ & 方 & $(073)$ \\
\hline 木 & & $<$ eng $>$ & 各 & $(175)$ \\
\hline \multirow[t]{2}{*}{ 叉雨 } & \multirow[b]{2}{*}{ m.in } & $<$ er> & 爻 & (269) \\
\hline & & $<\mathrm{er}_{2}>$ & 公 & (341) \\
\hline \multirow{3}{*}{\multicolumn{2}{|c|}{$\begin{array}{l}\text { bud nahan-er-en Raloon Tiluh } \\
\text { másik nagybácsi-k-nak a Raloon Tiluh } \\
\text { puši-en min } \\
\text { pusi [kínai cím]nak a sír[felirata], vagyis: } \\
\text { Az anyai nagybácsik közül való Dilu } \\
\text { nemzetséghez tartozó Raloon pusi } \\
\text { sír(felirata). }\end{array}$}} & $<\mathrm{es}>$ & 33 & $(146)$ \\
\hline & & $<\mathrm{eu}>$ & 去 & (067) \\
\hline & & $\begin{array}{l}\text { Az írásjel } \\
\text { hosszúság } \\
\text { nincs han } \\
\text { megkülön } \\
\text { A felemel } \\
\text { A jelekhe } \\
\text { használta1 }\end{array}$ & $\begin{array}{l}\text { k, mint ve: } \\
\text { vagy az inc } \\
\text { jlö szerepü } \\
\text { tetésül szol } \\
\text { ontozott írá } \\
\text { Menksoft fo }\end{array}$ & $\begin{array}{l}\text { ző, } \\
\text { xeknek } \\
\text { csak } \\
\text { alnak. } \\
\text { el. } \\
\text { tjait }\end{array}$ \\
\hline \multicolumn{5}{|c|}{ Megjegyzés a fordításhoz: } \\
\hline \multicolumn{5}{|c|}{$\begin{array}{l}\text { A „másik nagybácsik” a kitanokkal házassági rendszerben élő ujgurok egyik neve. Raloon személynév, } \\
\text { valószínüleg Arlon-nak vagy Arlun-nak olvasandó. A Tiluh a nemzetségnév, a kínai forrásokból jól } \\
\text { ismert Dilu. A puši a kínai fushi 'alparancsnok, almegbízott'. Az -er kollektívumképző, az -en a birtokos } \\
\text { eset jele. }\end{array}$} \\
\hline
\end{tabular}

${ }^{1}$ A feliratnak két kiadása van, Wu-Janhunen (2010) és Cinggeltei-Wu-Jiruhe (2017). 


\section{A MEGFEJTÉS}

A kitan nyelv megfejtése a vártnál lassabban halad. Egy-egy szó, kifejezés megfejtéséhez több segítség vehetö igénybe. Az első, ha van, a kínai eredeti vagy a kínai párhuzam. A második az alapszó mongol párhuzama, megfelelése, ha ilyen létezik, és végül természetesen a szövegösszefüggés. A nagy korpuszban ma már könnyen megtalálható egy-egy szó helyesírási változata, eltérő rögzítése. A ma is beszélt mongol nyelvek között a kitan szavak megfejtésében fontos szerepe van az Északnyugat-Kínában beszélt dahurnak. Ebben a három nyelvjárásban beszélt, ma a mongol nyelvek közé sorolt idiómában egy jelentős kitan összetevő őrződött meg. Számos kitan szó, néhány nyelvtani jel, illetve jelentés csak a dahurban van meg. Egyes vélemények szerint a dahur a máig fennmaradt, erösen elmongolosodott kitan, mások szerint a dahur egy mongol nyelv, amely erős kitan hatás alá került.

Meglepő módon a kitan alaktan, a képzők és ragok, jelek rendszere az egyes nyelvtani elemek azonosítása jutott leginkább előre. Ismerjük a kitan fönévragozást és a többes jeleket, valamint az igeképzők egy részét (müveltető, passzív képzőket). Azonosították a melléknévi igenevek képzőinek egy részét és a múlt idő jeleit. A kitanban, ahogy a középmongolban, nincsenek igei személyragok. Nagyon fontos volt a kitan számnevek azonosítása. A hatos számjegynek csak a jelét ismerjük, annak kiejtését még nem, a többi számjegy kiejtését megfejtettük (Róna-Tas, 2016). A megfejtett számnevek tövei azonosak a mongol számnevek töveivel. Sikerült nemrég a létigék és két tagadószó, valamint az égtájak neveinek (Róna-Tas, 2019) azonosítása is.

A meglepetések közé tartozik, hogy a kitanban létezik nyelvtani nem. Ez elöször az írás megfejtése közben tủnt fel, ugyanis egyes írásjeleknek van ponttal ellátott és pont nélküli alakja. Erről egy kínai kutató feltételezte, hogy a pont a hímnemủ alak elkülönítésére szolgál. A pont nélküli alak a nőnemet jelöli, vagy általános alak. A hím- és nőnem megkülönböztetését később sikerült képzőkön is kimutatni, majd egy-két esetben igealakokon is. Ez azért szenzáció, mert az ún. altaji nyelvekben, így a törökben, a mai mongolban és a mandzsu-tunguz nyelvekben, de az újabban egyesek szerint idesorolt koreaiban és japánban sincs nyelvtani nem. Természetesen azonnal két vélemény jelentkezett, az egyik szerint a nyelvtani nem a kitanban másodlagosan alakult ki, a másik vélemény szerint ősi, és a többiekben mindenhol eltünt.

A kitan szókészletből mintegy háromszáz szónak van biztos vagy valószínü megfejtése. Azonban ezek jelentős csoportja kínai tisztségnév, szakkifejezés, személynév. A megfejtett szavak egy részét még a kínai forrásokból ismertük, ahol a kitanokról szóló tudósításokban olyan megjegyzések is olvashatóak, hogy ezt és ezt a kitanok nyelvén így és így nevezik, például az ötös számot taw-nak mondják. Mivel a klasszikus mongolban az 'öt' tabun, a beszélt nyelvben tawn, világos hogy a két szó történetileg azonos. A dátumok meghatározásánál használt, 
az égövi állatjelek azonosításakor a kínai forrás megadta, hogy például a nyúl év esetén a nyúl szó a kitanban taulia. A mongolban ez taulai, a török tabišqan szabályos megfelelője. A kitan megfejtések második csoportját a kínai jövevényszavak alkotják. A kitan feliratokban igen sok a kínai szó, de ezek idegen szavak, nem váltak a kitan nyelv részévé, csak kitan átírásuk van. Egy kisebb csoport kínai szavai azonban a kitan nyelvbe kerülve ott például ragozhatókká váltak. Ilyen a pusin 'hölgy, asszony' jelentésủ szó. Ez a kínai furen átvétele. Mivel a kitanban nem volt f hang, azt p-vel helyettesítették. Birtokos esete pusinyen, amiböl kiderül, hogy az alapszó magas hangú volt, tehát a birtokos eset püsinyennek olvasandó. Ebből (és más példákból) tudjuk, hogy a kitanban magas hangú és mély hangú magánhangzó-harmónia volt.

A megfejtett szavak harmadik csoportjába azok a szavak tartoznak, amelyeket mongol megfelelöjük alapján sikerült azonosítani. Ilyen például a pülüg, amely az interkaláris hónap neve, jelentését a kitan nyelvủ dátum kínai megfelelése alapján tudjuk azonosítani. A kitan szó párhuzamai az irodalmi mongolban ülügü, ilegü, a közép-mongolban hülewü, a mai mongol nyelvekben $\ddot{u} l \bar{u}$, ilü alakban fordul elö, és 'többlet'-et jelent.

A megfejtett szavak negyedik csoportjába a szövegösszefüggés alapján kikövetkeztetett jelentésủ szavak tartoznak. Ilyen például a 'hivatali cím, név' jelentésű iri, többes száma iris, amelynek a mongol nere, 'név' szóval való összefüggése vitatott, vagy a nahadzsu, 'anyai nagybácsi, anyai ági férfi rokon', kitan nahaner, a kitanokkal házassági rendszerben élő anyai nagybácsik csoportját jelölő szó, lásd mongol naqa, 'az anya bátyja', nagacsu, 'anyaági férfi rokon'. Ez a csoport a legnagyobb. Egy kisebb alcsoportot alkotnak azok a kitan szavak, amelyek ugyan megvannak a mongolban, de más jelentéssel. A kitanban dege-, 'meghalni', a mongolban kikövetkeztethetö egy * dege-, 'felemelkedni, felfelé mozogni', de csak ilyen alakokban van meg, mint degere, 'fent, felül, felsö', degedü, 'felső, elözö' stb.

Az ötödik csoportba azok a szavak tartoznak, amelyeknek nincs, vagy eddig nem sikerült mongol megfelelöt találni. Ilyen például a semii,- 'betegnek lenni'.

A hatodik csoporba sorolhatók a különbözö eredetü, de nem kínai jövevényszavak. Ilyenek például a szogd eredetü usgi, 'betü, írás, nyelv', lásd mongol üsüg, ótörök üjeg, szogd üjüg, vagy a kitan te-, 'mondani, szólni', amely a tiszteleti nyelvben fordul elö, az ujgurból származik, és ilyen kifejezésekben található: usgi tegu, 'a [császári] irat így szól'.

\section{A KITAN NYELV HELYE AZ ALTAJI NYELVEK KÖZÖTT}

A nemzetközi tudományban az utóbbi időben felélénkült a vita arról, hogy az altaji nyelvek, vagyis a török, a mongol és a mandzsu-tunguz, esetleg a koreai és a japán nyelvek rokonok-e. A vita állásáról magyar nyelven legutóbb Grezsa 
István Bence (2014) tudósított. Az én álláspontom, amelyet számos publikációban (lásd legutóbb Róna-Tas, 2018) kifejtettem, a következő: az a szóanyag, amelyet a kutatás elsősorban Gustaf John Ramstedt és Nicholas Poppe munkássága alapján altaji közös ősnyelv részeként határoz meg, jövevényszó, mégpedig zömmel a mongolban és tunguzban, és ott török eredetü. Ilyen például a mongol ikire, török $i k i z$, magyar $i k e r$. Csak a törökben van $i k i$ kettő, az a mongolban kojar vagy dzsirin, a tunguzban *dzsür. Ha ezt a réteget módszeresen leválasztjuk, marad egy jóval kisebb, de fontos szóanyag, amely lehet, hogy egy közös ősi altaji szókincsből származik.

Az altaji nyelvek több ezer éves együttélése egy bonyolult és sürü hálózatot hozott létre, ennek egyik része a mongol nyelvek alhálózata. Ezen belül a kitan egy külön ágat képvisel, és a mongol-kitan nyelvcsalád tagja. Juha Janhunen (2012) a kitant egy paramongol nyelvként határozta meg.

\section{MAGYAR VONATKOZÁSOK}

A kitan nyelv megfejtése során egyre több olyan szó bukkan fel, amelynek párhuzama a magyar nyelvből is ismeretes. Ezek ugyanabból a török nyelvből kerültek a kitanba, mint a magyarba. Legutóbbi monográfiánkban (Róna-Tas et al., 2011) csak azt tudtuk jelezni, hogy a magyar szó párhuzama megvan a mongolban is, bár a nyomdába kerülés elött a könyv Addendájába (1493. oldal) már be tudtam szúrni egy kitan párhuzamot. Most gyülnek az olyan szavak, amelyek a kitanban is előfordulnak.

Ilyenek például a kitan teqoa, 'tyúk' a magyarba átkerült nyugati türk tiguk szabályos megfelelöje, az uri, 'herceg, előkelő' a magyar úr párhuzama, a kitan üni, 'szarvasmarha, zodiákus egy jele' a magyar ünő megfelelője. Párhuzamokat találunk néhány más magyar szóhoz is, így például a serleg szavunkban lévő serelem, egy eredetileg 'lakk' jelentésű, a kínaiból törökbe átkerült szó, megvan a kitanban is $s i(r)$ alakban. Az eredetileg 'tízezer' jelentésủ tömény szavunk párhuzama a kitanban tum alakban bukkant fel, és számnévi jelentése mellett katonai egységet is jelöl.

A kitan szövegek gazdagok személynevekben. Ezek között több török-ujgur is van. Itt is előfordul olyan, amelynek magyar párhuzama ismeretes. Ilyen a Sarhan, amely a magyar sárkány szavunk megfelelöje, korai magyar személy és családnévként is előfordul, vagy a Tömör $r$ amelynek eredeti jelentése 'vas', a magyarban is előfordult az Árpád-korban a Temer, Tymer személynevekben (Fehértói, 2004, 745.).

A kitanból előkerülő magyar vonatkozású adatok a magyar nyelv török kapcsolatainak ázsiai hátterét világítják meg. 


\section{ÖSSZEFOGLALÁSÉS KITEKINTÉS}

A mongollal rokon kitan nyelv és az azt megjelenítő írások megfejtése szemünk elött zajlik. Ugyanakkor a kitan honfoglalás Kínában, a kitan nomád törzsszövetség társadalmi, gazdasági és politikai szövete különbségeket és párhuzamokat mutat az egyidejü magyar társadalommal, a magyar honfoglalással és az Árpád-korral, így vizsgálata önismeretünkhöz is hozzájárul (lásd Róna-Tas, 1996). Nem véletlen tehát, hogy Ligeti és tanítványai, utódai a kitan írás és nyelv megfejtésében jelentős szerepet játszottak és játszanak. Egy alakulóban lévő magyarkínai munkacsoport előtt izgalmas feladatok tornyosulnak. Ilyen lesz, többek között egy kitan-angol etimológiai szótár összeállítása, melyhez az előmunkálatok már megkezdődtek.

Az ilyen kutatások járulnak hozzá a magyarság múltjának megismeréséhez.

\section{IRODALOM}

Apatóczky Á. B. - Kempf B. (2017): Recent Developments on the Decipherment of the Khitan Small Inscriptions. Acta Orientalia Hungarica, 70, 109-133. DOI: 10.1556/062.2017.70.2.1, https://www.researchgate.net/publication/317969942_Recent_developments_on_the_decipherment_of_the_Khitan_Small_script

Apatóczky Á. B. - Róna-Tas A. (2019): A New Comprehensive Monograph on Khitan, Acta Orientalia Hungarica, 72, 2, 259-268. DOI: 10.1556/062.2019.72.2.7, http://real.mtak.hu/94892/

Chinggeltei (2002): On the Problems of Reading Kitan Characters. Acta Orientalia Academiae Scientiarum Hungaricae, 55, 99-114. DOI: 10.1556/AOrient.55.2002.1-3.8, https://www.researchgate.net/publication/250979775_On_the_Problems_of_Reading_Kitan_Characters

Chinggeltei - Wu Yingzhe - Jiruhe (2017): Qidan xiaozi zai yanjiu I-III. 契丹小字再研究 [Further Research on Khitan Small Script], Beijing

CWJ lásd Chinggeltei - Wu Yingzhe - Jiruhe (2017)

Daniels, P. T. - Bright, W. (eds.) (1996): The World's Writing Systems. Oxford: Oxford University Press

Fehértói K. (2004): Árpád-kori személynévtár (1000-1301). Budapest: Akadémiai Kiadó

Grezsa I. B. (2016): A legújabb viták az altaji nyelvrokonságról. Nyelvtudományi Közlemények, 112, 323-337. https://bit.ly/2VMLuhx

Janhunen, J. (2012): Khitan: Understanding the Language Behind the Script. SCRIPTA, 4, 1-36.

Kane, D. (2009): The Khitan Language and Script. Leiden-Boston: Brill

Kara Gy. (1996): Siniform Scripts of Inner Asia: Kithan and Jurchen. In: Daniels, P. T. - Bright, W. (eds.) (1996): The World's Writing Systems. Oxford: Oxford University Press, 230-239.

Kervyn, L. (1923a): La tombeau de l'empereur Tao-tsong (1101)-Une découverte intréssante, Bulletin Catholique de Pekin, 10, 292-301.

Kervyn, L. (1923b): La tombeau de l'empereur Tao-tsong des Liao, et les premières inscriptions. T'oung Pao, 22, 292-301.

Ligeti L. (1927): A kitaj nép és nyelv. Magyar Nyelv, 23, 293-310. https://library.hungaricana.hu/ hu/view/MTAKonyvtarKiadvanyai_BORA_02/?query=kitaj\&pg=7\&layout=s Hungaricana oldalszám: 191-208. 
Róna-Tas A. (1999): Honfoglalás és népalakulás a középkori Eurázsiában. Kitajok, avarok, magyarok. (1996) In: Székfoglalók a Magyar Tudományos Akadémián. Budapest: MTA, 1-17.

Róna-Tas A. (2016): Khitan Studies I. The Graphs of the Khitan Small Script. 1. General Remarks, Dotted Graphs, Numerals. Acta Orientalia Academiae Scientiarum Hungaricae, 69, 117-138. http://real.mtak.hu/38020/1/062.2016.69.2.1.pdf

Róna-Tas A. (2018): A kitan nyelv helye az altaji nyelvek rendszerében. In: Dallos E. - Kósa G. (szerk.): Kultúrák találkozása és kölcsönhatása a Selyemút mentén. Ecsedy Ildikó születésének 80. évfordulójára. Budapest: MTA-ELTE-SZTE Selyemút kutatócsoport, ELTE Konfucius Intézet 227-247.

Róna-Tas A. (2019): The Khitan Names of the Five Capitals. International Journal of Eurasian Linguistics, 1, 98-124. DOI: 10.1163/25898833-12340006

Róna-Tas A. - Berta Á. - Károly L. (2011): West Old Turkic. Turkic Loanwords in Hungarian. 1-2. (Turcologica Book 84) Wiesbaden: Harrassowitz

Wittfogel, K. - Fêng, Chia-shêng (1949): History of Chinese Society: Liao (907-1125). Philadelphia The American Philosophical Society-Macmillan

Wu, Yingzhe - Janhunen, J. (2010): New Materials on the Khitan Small Script, A Critical Edition of Xiao Dilu and Yelü Xiangwen. Folkestone: Brill

Wu, Yingzhe - Jiruhe - Peng Daruhan (2017): Interpretation of the Epitaph of Changgun Yelü Zhun of Great Liao in Khitan Large Script. Acta Orientalia Academiae Scientiarum Hungaricae, 70, 217-251. DOI: 10.1556/062.2017.70.2.5 